\author{
Julija Korostenskienè \\ Vilnius University, Lithuania
}

\title{
ON SOME PROPERTIES OF THE ASPECTUAL PROJECTION AND VERBAL MOVEMENT IN RUSSIAN AND LITHUANIAN
}

Summary. Set within the generative syntactic framework, the present study explores the aspectual projection in Russian and Lithuanian. As is known, aspect is traditionally regarded to be a grammatical category in Russian, whereas there is no unanimous view on Lithuanian aspect and the latter is perceived within the lexical or lexico-grammatical range. Given the fact that both Lithuanian and Russian exhibit the features of languages with the verb merged low on the syntactic tree, while their general morphosyntactic properties are similar in many respects, e.g., rich verb morphology, tense and agreement systems, the verb may be derived by both prefixation and suffixation. Different aspectual properties present an interesting puzzle. The article aims to provide a formal account for this phenomenon. It is first shown that, similarly to Russian, the Lithuanian verb is positioned low, which is reflected in the regular appearance following manner adverbs. However, due to the varying feature strength of the relevant functional projections in each language, verbal movement in each language is realised differently, which consequently affects the morphemic layout as well as has implications for the aspect-tense correlation in each language.

Keywords: aspect, Lithuanian, morphosyntax, movement, Russian, verb.

\section{Introduction}

Within the generative tradition, Russian and Lithuanian are regarded as languages with the verb occupying the position low on the syntactic tree, as evidenced by the adverb placement test in which the adverb precedes the verb in both languages, similarly to English but different from French, where the adverb follows the verb, e.g.:
a) Tom fait souvent des exercices.
French
b) Tom often exercises.
English
c) Томас часто делает зарядку.
Russian

Tomas often do-3.PRS exercise-SG.ACC

Tomas often exercises.

d) Tomas dažnai daro mankštą.

Lithuanian

Tomas often do-3.PRS exercise-SG.ACC

Tomas often exercies. 
Given other well-known similarities between Russian and Lithuanian, such as rich verb tense and agreement systems and active derivation by prefixation and suffixation, it is interesting to explore why the two languages should exhibit striking aspectual differences. Russian aspect is perceived as possessing features of the addition of a prefix to the imperfective verbal stem which makes the verb perfective (e.g., Corre, 2015; Holvoet, 2001; Holvoet \& Čižik, 2004; Svenonius, 2004b, 2004c; Tatevosov, 2015). In Lithuanian, the addition of the prefix does not necessarily perfectivise the verb and, regardless of the resultative prefix, it may still have an imperfective reading. Consequently, Lithuanian aspectual system is at best regarded as lexico-grammatical. The examples below illustrate the point:

a) Ученик быстро делает/ *сделает уроки. (in the non-resultative reading)

Pupil-SG.NOM quickly do-3.PRS/pref-do-3.PRS

lessons-PL.ACC

The pupil prepares lessons quickly.

(b) Mokinys greitai daro/padaro pamokas.

Pupil-SG.NOM quickly do-3.PRS/pref-do-3.PRS lessons-PL.ACC

The pupil prepares lessons quickly.

In the Russian example, the appearance of a perfective prefix on the verb changes the aspect of the originally imperfective stem to perfective (Ru. delat'sdelat'), consequently, blocking non-resultative reading of a construction with a prefixed verb; in Lithuanian no such change occurs and the prefixed verb form is still interpreted as imperfective. Meanwhile both Russian and Lithuanian prefixes can have spatial, directional and idiomatic meanings (Korostenskienè, 2015). The data of the two languages suggest that there exists an interplay between tense and aspect: in interpreting the composition of the Russian verb in (2), resultative reading wins over temporal, while for Lithuanian the opposite is true.

The present study aims to examine several factors involved in this phenomenon. The objective will be to identify the differences in the behaviour of the two verbal systems and suggest a possible explanation for the realisation of the aspectual parameter in both languages. The article is structured as follows: first, the relevant theoretical background is provided; then the main findings of 
the generative approach to the Russian and Lithuanian verbal prefixation systems are discussed; finally, the phenomena responsible for the layout of aspectually relevant morphemes in the two languages are explored and a formal solution is provided.

\section{Theoretical background}

The basic structure of the sentence in generative syntax is perceived as a hierarchical structure with an optionally filled complementiser phrase (CP), branching down into the mandatory TP (Tense Phrase), further subdivided into a Noun Phrase and the head $\mathrm{T}$, the bearer of tense, which then branches into $a$ light verb phrase VP for causative constructions (distinguished for all agent arguments and, depending on the approach, experiencer verbs) and then the lexical verb Verb Phrase (the only available verb head for thematic/unaccusative verbs). The light verb head may either have an empty head or be filled with a causative affix. Following the principles of the Distributed Morphology, a domain in generative syntax specifically concerned with the interaction and rules that determine the distribution of morphemes in the word, all processes are the result of application of two major syntactic operations: Merge and Move (Embick \& Noyer, 2007). The order of morphemes is argued to be universal, but subject to language-dependent Move operations due to variable feature strength of a given parameter. It is notable that, while syntax may induce changes in the morphology, this will only be relevant at the morphological level (Anderson, 1989). Under this approach, any word may be represented by means of syntactic notation and, given the tight relation between syntax and morphology, DM postulates that the morphological structure of the word is primarily syntactic, i.e., follows the same hierarchical order as developed for the sentence and is governed by the Mirror Principle, whereby, depending on the form of the word, the functional categories $Z P, Y P$, and $X P$, responsible for tense and agreement, for example, may be realised to the left of the root (for prefixation) or to the right of the root (for suffixation) (Embick \& Noyer, 2005).

If the hierarchical view of the sentence and the verb as being part of this hierarchical structure is accepted, it then follows naturally that "tense, aspect, mood and polarity are features of the clause" (Kibort, 2008, n.p.) as they are 
structurally positioned above the verb, with aspect cross-linguistically taking a closer position to the verb than tense marking (Julien, 2002, Appendix 2). In generative linguistics, extensive research has been conducted on identifying the relationship between the tense and the verb with languages divided, following Pollock's (1989) work, into verb raising languages, such as French, and non-verb raising languages, such as English. This conclusion stemmed from a series of diagnostic tests, one of the most frequently cited being the adverb placement test which proceeded from the assumption that adverbs are positioned in a strictly organized hierarchy with low adverbs, such as frequency and manner, taking the lowest positions on the hierarchy and consequently the closest positions to the verb. For French and English, Pollock (1989) showed that, while the French verb is followed by low adverbs, in English low adverbs precede the verb. Since in Russian and Lithuanian, in neutral contexts low adverbs systematically precede the verb (Dyakonova, 2009; Korostenskienè, 2015), Russian and Lithuanian can be grouped together with English suggesting that the verb undergoes raising to tense after spell-out, since rightward movement is blocked (Kayne, 1994).

In addition, in his examination of the place of attachment of manner adverbs, Katz (2000) shows that they in fact adjoin not to the verb itself, but to an aspectual projection above it. Katz compares dynamic and state verbs to state that, whereas dynamic verbs combine with manner adverbs and state verbs do not, the property that differentiates between the two types of verbs is aspectual in nature: dynamic verbs have an empty eventive head $e$, state verbs do not.

\section{An overview of Russian and Lithuanian verbal prefixation systems}

As is known, aspectual information on the verb in Lithuanian and Russian may appear both in prefixed form, as a resultative prefix (e.g., Lt su-, Rus po-), and in suffixed form, as, e.g., a secondary imperfective suffix (Lt -iné, Rus -yva-). In addition, Svenonius (2004a, 2004b, 2004c) distinguishes a class of superlexical prefixes in Russian and Korostenskienè (in print) extends his methodology to argue for the respective class in Lithuanian. Prefixes in the two languages are subdivided into lexical prefixes and superlexical prefixes. Lexical prefixes are of prepositional origin and are related to Germanic particles. Due to their ability to convey idiosyncratic meanings, following Marantz's (1984) principle 
of idiom formation, and the fact that they are frequently duplicated by their respective prepositions, lexical prefixes are argued to merge below the verb as prepositions and then move to the aspectual projection above the verb to get the resultative reading. Superlexical prefixes are argued to have the nature of adverbial modifiers; they merge above the verb in the respective projection by adjunction, convey strictly compositional meanings, and can stack on other prefixes within the verbal complex. In her analysis of Lithuanian superlexical prefixes, Korostenskiene (2015) notes that the class of superlexical prefixes in Lithuanian is more heterogeneous than its counterpart in Russian: while the Russian superlexical prefixes are all aspectual, of the three simple Lithuanian superlexical prefixes te-, ne-, and be-, only be- has aspectual (progressive) reading, while -te- and -ne- are argued to have more clause-like properties and, considering previous analyses (Arkadiev, 2014a,b, 2011a,b, 2010), their respective functional projections are to be attributed to modality and negation. Interestingly, manner adverbs can adjoin to the modal superlexical te-, which is in line with an opinion attributing relative flexibility to adverb placement (e.g., Cinque, 1999; see Svenonius (2001) for a general overview), e.g.

(3) Patys institutai... noriai iš savo gèrybiu kai ką teduoda kitiems Bažnyčios reikalams ir vargdieniu, kuriuos visi vienuoliai nuoširdžiai temyli Kristuje, išlaikymui...

...religious communities should gladly use their own goods for other needs of the Church and the support of the poor whom all religious should love after the example of Christ...

The above discussion may be summarized as follows: the left boundary of the Lithuanian verb contains a significantly more heterogeneous amount of morphosyntactic material than Russian, but the crucial distinction of the verb's aspectual properties in both languages rests in the domain of lexical prefixes. The relationships holding within the verbal complex will be considered more closely. 


\section{Aspectually relevant morphemes: the puzzle and an approach}

Disregarding the superlexical material for a moment, which is all merged above the verb, and including the shared class of lexical prefixes as well as material positioned below the lexical prefix, the verbal morphemes in Lithuanian and Russian transitive and experiencer verbs then have the following order:

$$
\text { Asp }>\text { v }>\text { V }>\text { Asp }>\text { T }>\text { Agr }
$$

In the present order, there are two aspectual positions: one for resultative prefixes to the left of the verb, and one for aspectual suffixes to its right. Economy considerations of the generative approach would require that there should only be a single aspectual projection distinguished and, consequently, the appearance of two aspectual positions must be formally explained. How can this be handled?

Movement is a widely recognized, prevailing process considered to be responsible for all permutations across languages. One implication of blocking rightward movement on the syntactic tree was that the need to account for the diversity in the linear layout of the constituents still remained. This has led to distinguishing more refined types of movement which contrasted the (universally) initial and the (language-specific) final position of relevant elements on the tree. According to the minimalist perspective on movement, placement of two elements next to each other is not accidental but is rather stipulated by a certain functional projection with strong features that need to be checked (Svenonius, 2006). Consequently, if there are two elements $X$ and $Y$, such that $X$ is (universally and underlyingly) higher on the syntactic tree than $Y$, but in a given language $Y$ moves over $X$ and ultimately features higher than $X$, this is suggestive of $Y$ being attracted to a certain functional head $F$ with which it needs to check features.

Another complication is the availability of several orderings depending on which element in a sequence moves. Svenonius (2006) summarises the possible linear combinations of three items standing in hierarchical relationship to each other, all of which are attested in various languages, with ' 1 ' being "the highest and ' 3 ' the lowest $<\ldots$ >: 

a. $1-2-3$
Straight
b. $1-3-2$
Curl
C. $3-2-1$
Roll-up
d. $3-1-2$
Skipping
e. 2-3-1
Constituent Fronting or Sinking
f. $2-1-3$
Hopping
(Svenonius, 2006, p. 3).

In addition, the remaining part of the original material may move at a subsequent stage. This has been referred to as remnant movement: "Remnant movement is movement of an XP from which extraction of has taken place earlier in the derivation" (Müller, 2001, p. 1). For example, one of the operations taking place in the derivation of (6a) is argued to be remnant movement of the $\mathrm{VP}_{2}$, as shown in (6b) (Kayne, 1998):

a) Tom writes no poems.

Tom [VP2 writes $t_{1}$ ] no poems $t_{2}$

b) Tom no writes poems - Ordering prior to movement

Given the fact that what may be expressed at the level of syntax in one language may be rendered at the level of morphosyntax/morphology in another, it follows naturally that these mechanisms should be applicable to both syntactic units and morphemes alike.

In light of the movement types and affix layout in Lithuanian and Russian, it is worth examining the aspectual properties in the verb more closely. Since aspect is regarded to be a clausal property, the only (and) initial aspectual projection should appear above the verb. Indeed, in Russian examples with secondary imperfectives, Dyakonova (2009) argues, the imperfective has scope over the lexical prefix, which is suggestive of its initially higher position than that of the prefix. In addition specifier, Svenonius (2004) has demonstrated that, being of nominal origin, the prefix can only take the position within the aspectual projection, while lexical prefixes in particular, move there from a position below the verb in order to acquire the resultative meaning). Since in Lithuanian scopal relations, with the secondary imperfective scoping over the lexical prefix, are the same as in Russian, the process can be schematically shown as follows: 
(7)

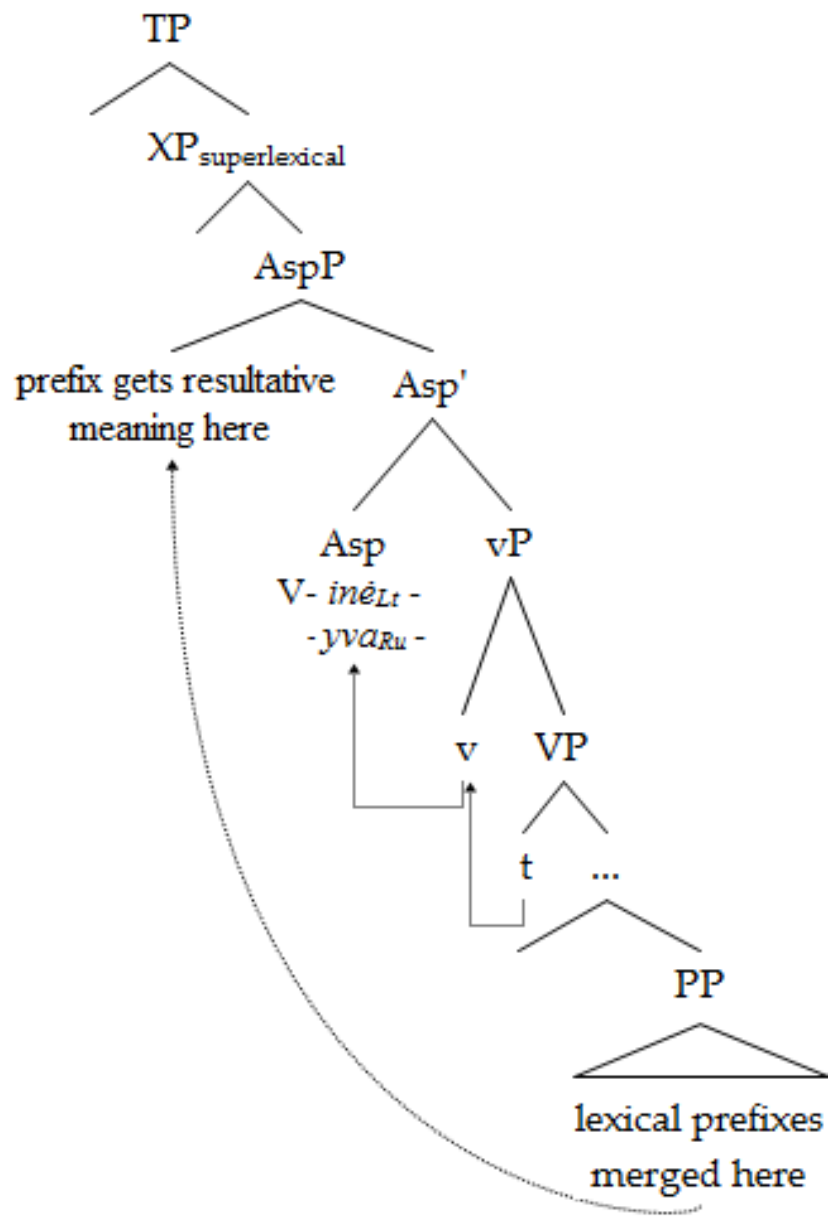

The example and the tree below ( 8 a, b) are after Dyakonova's (2009, p. 32) analysis and further illustrate the point:

(8) a) po -na- vy-kid- yva- $t$

SLP Del-SLPCum-LP-throw-2IMP-INF

'to throw out a lot of [items] one by one' 
b)

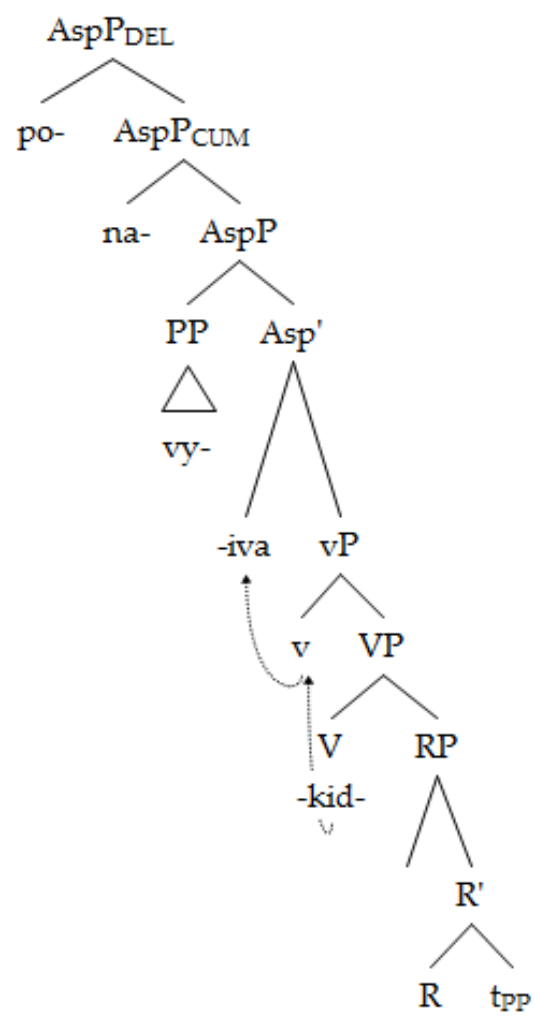

Since the lexical prefix has moved from a position below the aspectual phrase, the scopal relations within the verb are as follows:

(9) SLP $>$ Secondary Imperfective $>$ LP (Dyakonova, 2009, p. 32)

Let us also consider an example from Lithuanian:

(10) Ne-be-iš-met-inè-ti

SLPneg-SLPprog-LP-throw-2IMP-INF

'not to be throwing out [items] anymore' 
As has been stated above, the Lithuanian verb behaves in the same manner as the Russian verb. The issue, however, is complicated if we consider a reflexive verb:

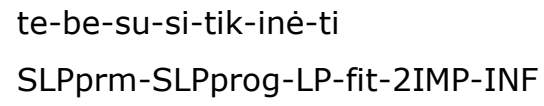

'To keep seeing/meeting each other'

As is known and as (11) illustrates, the material between the lexical prefix suand the secondary imperfective suffix -iné- contains both the verbal root -tik- and the reflexive marker -si. This order is contrasted by the verb final position of the reflexive marker in prefixless verbs and the fact that in Russian, the reflexive marker always follows tense and agreement morphology. Let us consider the process taking place here in greater detail.

Korostenskiene (2014, in print) argues that the reflexive marker is a physically manifest trace of the subject argument. As such, it is devoid of any other features and can only occupy the merging position of the sentence argument. Following Kratzer (1996), this position for agent and experiencer arguments is the specifier of the voice phrase, which also came to be perceived under the notion of $\mathrm{VP}$, and is the specifier of the lexical verb phrase VP for thematic verbs:

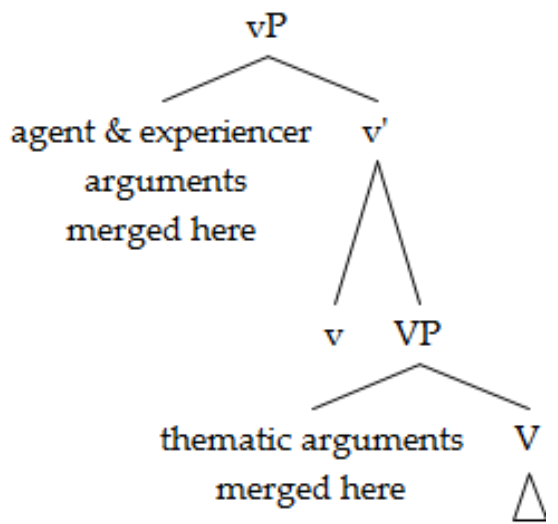


If so, in Lithuanian prefixed verbs the order si> $V$ is naturally stipulated and reveals the morphemic hierarchy on the tree. In the case of forms with the secondary imperfective, the complex has to occur above the aspectual marker, since, the theory blocks rightward movement and consequently the aspectual affix cannot lower to take the position after the verb. Given that the leftward movement is the only way, it may be argued that in the Lithuanian example (10) above, the lexical verb $\mathrm{V}$ first has to pass through the stage $\mathrm{VP}$, where it is leftadjoined by the reflexive marker, as it is merged in the specifier position of $\mathrm{VP}$, and then both of them move up to the aspectual phrase AspP headed by the secondary imperfective suffix -iné- and left-adjoin through incorporation (Baker, 1988).

In Russian, however, the reflexive marker is verb-final at all times even though the verb shows the same movement trajectory and takes the position preceding the secondary imperfective suffix:

$$
\begin{aligned}
& \text { Po-na-za-pis-yva-li-s } \\
& \text { SLPDel-SLPCum-LP-write-2IMP-PL.PAST-SI } \\
& \text { 'to sign up for sth one by one' (said of many agents) }
\end{aligned}
$$

Consequently in Russian, the reflexive marker always stays in its merging position while the verb obligatorily moves to the aspectual position. In Lithuanian, however, it is only in the prefixless forms that the verb moves to check and delete aspectual features.

Both languages exhibit roll-up movement in that the lexical prefix moves from the originally low position below the verb to the specifier of the aspectual phrase. Both Lithuanian and Russian exhibit remnant movement in that the material which is originally above the prefix and has remained in its position throughout the movement of the prefix, raises then, too, but with different force: in Lithuanian, the reflexive marker incorporates onto the verb and both move up to the aspectual position, as evidenced by their placement relative to the secondary imperfective suffix. In Russian, the reflexive marker does not incorporate onto the verb and the verb alone, while passing through the light verb, following the Minimal Link Constraint, undergoes remnant movement to the aspectual position and left-adjoins the secondary imperfective suffix. 
Let us also consider some more general properties of the verb raising parameter in Russian and Lithuanian. As has been mentioned before, both languages have their verbs merged low and they regularly appear following manner adverbs. In both languages the lexical verb undergoes the short verb movement from $\mathrm{V}$ to $\mathrm{v}$ (on its way to covert movement to $\mathrm{T}$ ) in order to acquire the causative/experiencer reading. However, in yes/no questions the languages show different behaviour with respect to further movement from $\mathrm{T}$ to $\mathrm{C}$ :

а) Пойдет ли он на вечеринку? Pref-go-3.M.FUT $Q$ he-NOM.SG. on party-SG.ACC

Will he go to the party?

b) Ar jis eis i vakarèli?

Q he-NOM.SG go-3.FUT in party-SG.ACC

Will he go to the party?

Compare this with French and English:

a.Voit-il le cheval?

b. *Sees he the horse? (Roberts 2001, p. 123)

In Russian, the verb precedes the interrogative complementiser li (14a); in Lithuanian, the verb follows its counterpart ar (14b). This suggests that, while in Russian the verb raises to the complementiser position in $\mathrm{C}$, in Lithuanian the verb follows both the complementiser and the subject of the sentence, hence does not move above $\mathrm{T}$. With reference to feature theory, the following line of reasoning may be sketched: in both languages the verbs are weak at $T$ in that, unlike French, they only raise to T covertly, i.e. after spellout - since they follow manner adverbs. In Russian, however, as in French, the feature ( $V$ or $T$ ) on $C$ is strong (Roberts, 2001, p. 125) hence the verb is forced to move up, whereas in Lithuanian, as in English for lexical verbs, it is weak, hence the Lithuanian verb follows the subject and remains at $\mathrm{T}$.

As regards the relocation of the reflexive marker in both languages, the connection between the reflexive and the verb is apparently stronger in 
Lithuanian than Russian. Since in Lithuanian prefixed verbs, the verb follows the reflexive marker, the $[\mathrm{V}]$ feature on the aspectual head should be weak, hence no attraction takes place, possibly also because the checking of the aspectual feature occurs between the aspectual head and its specifier; but in Russian the aspectual feature [V] on the aspectual head is strong in all forms, hence the verb obligatorily moves to the aspectual position, leaving the reflexive marker verbfinally. An idea that it must be stronger is also supported by the aforementioned Russian verb placement in yes/no constructions and, consequently, the need to be able to project higher on the tree relative to the Lithuanian verb. The Lithuanian verb, however, overtly rises to the aspectual projection in prefixless constructions, since there is no other way to check features as well as because the physically manifest trace of the subject is but residual material which cannot form the left boundary of the verb.

The fact that the aspectual feature is stronger in Russian than in Lithuanian finally helps explain why aspect wins over tense in finite verb forms in Russian. It turns out that the aspectual projection attracts two types of material: lexical prefixes on the one hand, and the verb itself on the other. Attraction of lexical prefixes allows the aspectual head to realise its aspectual feature by checking and deleting it with the lexical prefix positioned in its specifier (checking it in the specifier-head relationship). On the other hand, verb movement suggests that there is also a verbal feature on all relevant projections, i.e. Asp, T, and C, and the checking and deletion of features proceeds in the head-head relationship. As for features in $\mathrm{C}$, it may also be the case that $\mathrm{C}$ may exert certain EPP qualities requiring that its projection be filled with any phrase. This proposal has been made for V2 languages (Roberts, 2001), but may also be applicable here, since other phrases, e.g., adverbs or personal pronouns, take the same positions:

a) Часто ли он опаздывает?

adverb

Often $Q$ he-SG.NOM be-late-3.PRS

Is he often late?

b) $\mathrm{Ar}$ jis dažnai vèluoja?

Q he-SG.NOM often be-late-3.PRS

Is he often late? 
с) $\mathrm{OH}$ ли это?

$\mathrm{He} Q \mathrm{Q}$ this?

Is it him?

d) $\operatorname{Ar}$ tai jis?

Q this he

Is it him?

Hence, if we assume for convenience that the aspectual, tense, and complementiser heads in both languages have their own respective feature as well as the verbal feature $\mathrm{V}$, and that the relevant projections are Asp, $\mathrm{T}$, and $\mathrm{C}$, with the aspectual projection entering into the feature-checking process in both a specifier-head and a head-head relationship, the balance of features is as in the table below:

Table 1.

Checking features with the specifier filled by a lexical prefix (in the specifier-head relationship)

\begin{tabular}{|c|c|c|}
\hline Head & $\begin{array}{c}\text { Its respective feature in } \\
\text { Russian }\end{array}$ & $\begin{array}{c}\text { Its respective feature in } \\
\text { Lithuanian }\end{array}$ \\
\hline Asp & {$[$ Asp] Strong } & [Asp] Strong \\
\hline
\end{tabular}

Table 2.

Checking features with the head (in a head-head relationship)

\begin{tabular}{|c|c|c|}
\hline Head & $\begin{array}{c}\text { Its respective feature in } \\
\text { Russian }\end{array}$ & $\begin{array}{c}\text { Its respective feature in } \\
\text { Lithuanian }\end{array}$ \\
\hline Asp & {$[$ Asp/V] Strong } & {$[$ Asp/V] weak } \\
\hline$T$ & {$[T / V]$ Weak } & {$[T / V]$ Weak } \\
\hline$C$ & {$[C / V]$ Strong } & {$[C / V]$ Weak } \\
\hline
\end{tabular}


It is notable that the aspectual head in Lithuanian is strong enough to attract prefixal material. But what differs is that while in Russian the verb is always attracted to the aspectual projection (hence the aspectual feature is strong), in Lithuanian only prefixless verbs are attracted. Thus, the aspectual feature is relatively weak: it can only attract the prefix or the verb root, but not both. This is why in prefixless reflexive verbs the reflexive marker follows the verb: the verb has moved to the aspectual projection, but the reflexive marker has remained in its base position as a trace of the subject. In prefixed verbs, the aspectual feature-checking is satisfied by the moved prefix; hence the verb remains in its base position and is followed by the reflexive marker. Meanwhile in Russian, the verb always moves to the aspectual projection, which also suggests that the distinction of a separate verbal feature may be beneficial, as it may be stated then that the verb is attracted to the aspectual projection on independent grounds from prefixes. On this view, the verbal feature on AspP is strong in Russian, since the verb always moves. For uniformity considerations, the verbal feature on Asp is also to be distinguished for Lithuanian; but it is weak, therefore the verb remains in its base position in prefixed verbs and is forced to move in prefixless combinations as a last resort since the word boundary cannot be formed by a trace.

Let us also return to example $(2 \mathrm{a}, \mathrm{b})$ repeated below as $(19 \mathrm{a}, \mathrm{b})$ :

а) Ученик быстро делает/ *сделает уроки.

Pupil-SG.NOM quickly do-3.PRS/pref-do-3.PRS lessons-PL.ACC

The pupil prepares lessons quickly.

(b) Mokinys greitai daro/padaro pamokas.

Pupil-SG.NOM quickly do-3.PRS/pref-do-3.PRS lessons-PL.ACC

The pupil prepares lessons quickly.

These examples can now be re-interpreted in terms of feature strength, as listed in the tables above to explain why perfective aspectual meaning scopes over tense in Russian but does not do so in Lithuanian. Both Russian and Lithuanian have a strong aspectual head in relation to how prefixes move from a lower 
position to get the resultative meaning. In Russian and Lithuanian languages the tense head is weak; thus, adverbs regularly precede the verb. But the strength of the verbal feature in the relevant projections varies: in Lithuanian, the verbal feature is generally weaker. Therefore, when it comes to the stage of meaning construction on the basis of the morphological components of the verb, the material contained in the aspectual projection in Russian will have two advantages over the tense phrase: in Russian its aspectual and verbal features are set to be strong, hence can be seen overtly. In contrast, the verbal feature on the tense marker $\mathrm{T}$ will be weak and the movement of $\mathrm{V}$, or rather Asp, to $\mathrm{T}$, will take place covertly. Meanwhile in Lithuanian the aspectual feature is strong, but the verbal feature on Asp is weak, or at least weaker than in Russian and, phenomenally, two realizations of reflexive forms become available: the feature is manifested in its stronger form in prefixless forms, possibly because of the combination of the aspectual feature, which has remained unchecked in the absence of the prefix, and the verbal feature on the aspectual head. At the same time, in prefixed forms, the feature does not gain support from the aspectual feature and remains weak, hence the verb does not move overtly. This power balance results in the restrictive power of aspect on tense in Russian: aspectual features are stronger than tense ones. In Lithuanian, the aspectual projection is generally weaker, accordingly, the positions of tense and aspect are relatively the same in strength. Consequently, the hierarchical properties will matter: since tense is assigned higher up on the tree than is the locus of aspect, it will be tense that will have scope over aspect and not otherwise.

\section{Conclusions}

The present article examines the order of verbal morphemes in Russian and Lithuanian. Assuming the canonical linear order of constituents to hold crosslinguistically, the ability of Russian and Lithuanian verbs to render aspectual relations to both sides of the verb root within the verb is argued to be the result of movement which splits the aspectual position. The relative merging positions and reasons for movement of relevant elements are examined. It is argued that, while the aspectual projection above the verb may attract prefixes from their lower merging positions to realize resultative meaning in both Russian and 
Lithuanian, its aspectual and verbal features are of different strength in the two languages. The relative feature strength of aspectual, tense and complementiser positions is proposed. It is suggested that feature strength distinctions at these projections help account for the distinction of aspect as a grammatical category in Russian, but only as lexico-grammatical category in Lithuanian.

\title{
Abbreviations
}

\author{
ACC - Accusative \\ AspP - aspectual phrase \\ C - complementiser \\ CMLT - cumulative \\ CNT - continuative \\ DEL - delimitative \\ FUT - future \\ LP - lexical \\ Neg - Negative \\ NOM - Nominative \\ $\mathrm{PI}$ - plural \\ Pref - prefix \\ Prm - permissive \\ Prog - progressive \\ PRS - present \\ PST - past
}

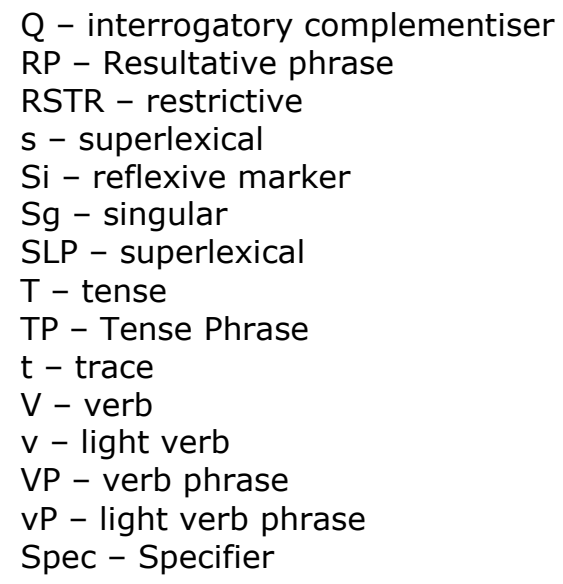

\section{References}

Arkadiev, P., (2010). Notes on the Lithuanian restrictive. Baltic Linguistics, I, 949.

Arkadiev, P., (2011a). Aspect and actionality in Lithuanian on a typological background. In: Langues baltiques, langues slaves, éd. par D. Petit, C. Le Feuvre et H. Menantaud, Paris, CNRS Editions, 2011, pp. 61-92.

Arkadiev, P., (2011b). On the aspectual uses of the prefix be- in Lithuanian. In Baltic Linguistics, 2(2011), 37-78.

Arkadiev, P., (2014a). Glagol'naja restriktivnost' v litvoskom jazyke. [Verbal restrictivity in Lithuanian]. Acta Linguistica Petropolitana, Studia typologica octogenario Victori Khrakovskij Samuelis filio dedicata, Nauka, pp. 12-42. 
Arkadiev, P., (2014b). Vzaimodejstvije perfekta $i$ otricanija v litovskom jazyke: areal'nja i tipologicheskaja perspektiva. [The interaction between perfect and negation in Lithuanian: an areal and typological perspective]. Retrieved from www.akademia.edu/101201497/Взаимодействие_перфекта_и_отрицани я_в_литовском_языке_ареальная_и_типологическая_перспектива.

Baker, M. (1988). Incorporation: a theory of grammatical function changing. Chicago: University of Chicago Press.

Cinque, G. (1999). Adverbs and the Universal Hierarchy of Functional Projections. Oxford University Press, New York.

Corre, E. (2015). "Preverbs in Russian: situation or viewpoint aspect?". Recherches linguistiques de Vincennes 1/2015 (No. 43), 97-122. Retrieved from: www.cairn.info/revue-recherches-linguistiques-devincennes-2015-1-page-97.htm.

Decree On The Adaptation And Renewal Of Religious Life Perfectae Caritatis Proclaimed By His Holiness Pope Paul Vi On October 28, 1965. Retrieved from http://www.vatican.va/archive/hist_councils/ii_vatican_council/document s/vat-ii_decree_19651028_perfectae-caritatis_en.html.

Dekretas dèl vienuoliškojo gyvenimo tinkamo atnaujinimo Perfectae Caritatis. Retrieved from http://www.Icn.It/b_dokumentai/vatikano_2s/perfectaecaritatis.html.

Dyakonova, M. (2009). A Phase-Based Approach to Russian Syntax. PhD dissertation. Amsterdam, the Netherlands.

Embick, D. \& R. Noyer. (2007). Distributed Morphology and the Syntax/Morphology Interface. In Oxford Handbook of Linguistic Interfaces), pp. 289-324.

Holvoet, A. (2001). Studies in the Latvian Verb. Krakow: Wydawnitctwo universytetu jagiellońskiego.

Holvoet, A. \& Čižik, V. (2004). Veikslas tarp kitu veiksmažodžio kategoriju. In: Holvoet, A., Semènienè, L. (eds.) Gramatiniu kategoriju tyrimai. Vilnius: Lietuviu kalbos institutas, pp. 141-162.

Julien, M. (2002). Syntactic Heads and Word Formation. Oxford University Press, New York. 
Katz, G. (2000). A semantic account of the stative adverb gap. In ZAS Papers in Linguistics, 17, 135-151. Retrieved from http://www.zas.gwzberlin.de/fileadmin/material/ZASPiL_Volltexte/zp17/zaspil17-katz.pdf.

Kayne, R. (1994). The Antisymmetry of Syntax. Cambridge, Mass.: MIT Press.

Kayne, R. (1998). Overt vs covert movement. Syntax 1, 128-191.

Kibort, A. (7 Jan 2008). Aspect. Grammatical Features. http://www.grammaticalfeatures.net/features/aspect.html\#third

Korostenskaja, J. (2014). Setting the verb raising parameter in Lithuanian. In: Kalbu studijos/Studies about Language, 25, 14-25.

Korostenskienè, J. (2015). On some properties of Lithuanian verbal prefixes. In Verbum, 6, UKI, Vilnius University, 95-122.

Korostenskienè, J. (2014). Exploring Lithuanian reflexive verbs from the generative perspective. In: Darbai ir dienos/Deeds and Days, 62, 59-80.

Korostenskienè, J. (in press). On the placement of the reflexive/reciprocal marker -si- in Lithuanian verbs. To appear in: Kalbu studijos/Studies about Language, KTU.

Kratzer, A. (1996). Severing the external argument from its verb. J. Rooryck and L. Zaring. (eds.). Phrase Structure and the Lexicon. Dordrecht, Kluwer, pp. $109-137$.

Marantz, A. (1984). On the nature of grammatical relations. Cambridge, Mass: MIT Press.

Müller, G. (2001). Two types of remnant movement. Retrieved from http://home.uni-leipzig.de/muellerg/mu6.pdf.

Pollock, J.-Y. (1989). Verb Movement, Universal Grammar, and the Structure of IP. In Linguistic Inquiry, 20, 365-424.

Roberts, I. (2001). Head-movement. In The Handbook of Contemporary Syntactic Theory, ed. by Marl Baltin and Chris Collins. Oxford, Blackwell.

Svenonius, P. (2001). Subject positions and the placement of adverbials. In Subjects, Expletives, and the EPP, ed. by Peter Svenonius. OUP: New York. Retrieved from http://hum.uit.no/a/svenonius/papers/SvenoniusSPPA02.pdf

Svenonius, P. (2004a). Russian prefixes are phrasal. Gerhild Zybatow, Luka Szucsich, Uwe Junghanns, Roland Meyer, and Peter Lang (eds). Formal 
Description of Slavic Languages, Frankfurt am Main 2008, pp. 526-537. Retrieved from http://ling.auf.net/lingbuzz/000043.

Svenonius, P. (2004b). Slavic prefixes and morphology: An introduction to the Nordlyd volume. In Nordlyd and Tromsø Working papers on Language and Linguistics 32.2: Special issue on Slavic prefixes, ed. by Peter Svenonius, pp. 177-204. University of Tromsø, Tromsø. Retrieved from http://septentrio.uit.no/index.php/nordlyd/index.

Svenonius, P. (2006). 1...3-2. In Oxford Handbook of Linguistic Interfaces, ed. by Gillian Ramchand and Charles Reiss, Oxford University Press, 2007. Retrieved from http://ling.auf.net/lingbuzz/000200.

Svenonius, P. (2004c). Slavic prefixes inside and outside VP. In Nordlyd, Troms $\varnothing$ Working Papers on Language and Linguistics 32.2: Special issue on Slavic prefixes, edited by Peter Svenonius, pp. 205-253. University of Troms $\emptyset$, Tromsø. Retrieved from http://septentrio.uit.no/index.php/nordlyd/issue/view/8.

Tatevosov, S. (2014). Perfectivity in Russian: A modal analysis. In Proceedings of the 44th Annual Meeting of the North East Linguistic Society. Edited by Jyoti Iyer and Leland Kusmer. Volume 2. Amherst: GLSA, 196-210. Retrieved from http://otipl.philol.msu.ru/staff/people/tatevosov/tatevoso.pdf

Tatevosov, S. (2015). Severing imperfectivity from the verb. In Slavic Grammar from a Formal perspective. Ed. by Zybatow, Gerhild, Petr Biskup, Marcel Guhl, Claudia Hurtig,Olav Mueller-Reichau, \& Maria Yastrebova. Farkfurt: Peter Lang, pp. 465-494. Retrieved from http://otipl.philol.msu.ru/staff/people/tatevosov/tatevosov_fdsl_rev.pdf. 


\section{Julija Korostenskienè}

Vilniaus universitetas, Lietuva

julija.korostenskiene@uki.vu.It

\section{APIE KAI KURIAS VEIKSLO PROJEKCIJOS BEI VEIKSMAŽODŽIO JUDĖJIMO SINTAKSINIAME MEDYJE SAVYBES RUSU IR LIETUVIU KALBOSE}

Santrauka. Straipsnyje analizuojama veikslo funkcinès projekcijos pozicija sintaksiniame medyje bei stiprumas lietuviu ir rusu kalbose. Veikslas rusu kalboje tradiciškai yra suvokiamas, kaip turintis daugiau gramatinès kategorijos požymiu. Lietuviu kalboje nuomonės išsiskiria ir veikslui priskiriami leksinès - gramatinès kategorijos bruožai. Abi kalbos turi panašia morfosintaksinę struktūra, laiku bei kaitybos sistemas, o generatyvinès sintaksės analizè atskleidžia dar viena panašuma, jog lietuviu bei rusu kalbose veiksmažodis sintaksiniame medyje užima žemą pozicija. Todèl skirtingas veikslo kategorijos pasireiškimas - idomi problema. Veikslo skirtumus straipsnyje bandoma aiškinti, pasitelkiant generatyvinès sintaksès nuostata, jog judejjimas sintaksiniame medyje yra salygojamas atitinkamos projekcijos bruožu stiprumu (angl. feature strength). Teigiama, kad abiejose kalbose veiksmažodžio morfosintaksinejje struktūroje vyksta taip vadinami susirietimo bei atliekantis/likutinis judejjimai (angl. roll up movement bei remnant movement). Remiantis abieju kalbu morfosintaksine sandara bei atsižvelgiant i sangrąžos dalelytès pozicija, straipsnyje ivertinamas laiko, veikslo bei veiksmažodžio projekciju stiprumas.

Pagrindinès sạvokos: judejjimas, lietuviu kalba, morfosintaksè, rusu kalba, sangražos dalelytè, veikslo kategorija, veiksmažodis. 